\title{
Tardigrades, Water Bears, Moss Piglets Tardigrada (Spallanzani 1777) ${ }^{1}$
}

\author{
Carrie Suen and Jennifer L. Gillett-Kaufman²
}

\section{Introduction}

Tardigrades, commonly known as water bears, are a type of microscopic animal found across a vast array of moist and aquatic environments. Tardigrades are known for their extensive resilience since they are also found in extreme environments such as Antarctica, deep sea vents, and mud volcanoes. An experiment conducted in 2008 discovered that tardigrades can survive and recover from exposure to the vacuum of space (Jönsson et al. 2008). They are commonly used as a model organism for scientific research relating to ecology, as extremophiles, and genetics.

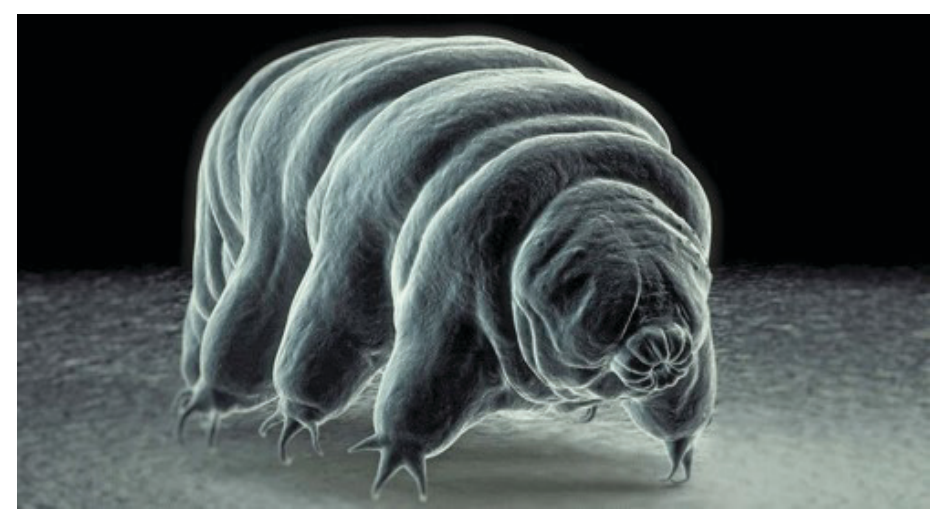

Figure 1. Image of a tardigrade done with electron microscopy. Credits: Encyclopedia Britannica (https://www.britannica.com/animal/ tardigrade/images-videos\#/media/1/583460/216626)

\section{Distribution}

Tardigrades are found virtually all over the world in marine, freshwater, and terrestrial environments. Most tardigrades require water to be active; however, terrestrial tardigrades are limnoterrestrial meaning that they live in moist environments such as in mosses and leaf piles. In periods of drought, tardigrades enter a dehydrated state until more suitable conditions become available. They are able to achieve this dehydrated state using special proteins and a sugar called trehalose (Boothby et al. 2017).

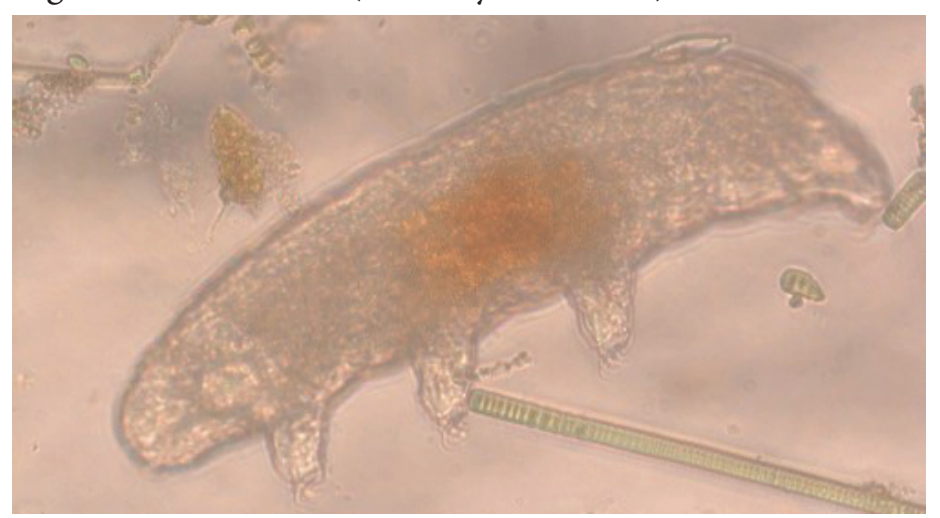

Figure 2. Image of Antarctic tardigrade collected near Lake Fryxell. Credits: J. Parr McQueen, University of Florida

\section{Description and Life Cycle}

Tardigrades are small invertebrates that range from $0.1 \mathrm{~mm}$ to $1 \mathrm{~mm}$ in length. They were described as little water bears during their initial observation in 1773 by zoologist August

1. This document is EENY-753, one of a series of the Entomology and Nematology Department, UF/IFAS Extension. Original publication date May 2020. Visit the EDIS website at https://edis.ifas.ufl.edu for the currently supported version of this publication. This document is also available on the Featured Creatures website at http://entomology.ifas.ufl.edu/creatures.

2. Carrie Suen and Jennifer L. Gillett-Kaufman, Extension scientist; Entomology and Nematology Department, UF/IFAS Extension, Gainesville, FL 32611.

The Institute of Food and Agricultural Sciences (IFAS) is an Equal Opportunity Institution authorized to provide research, educational information and other services

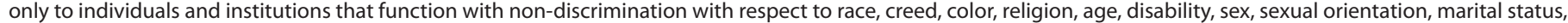

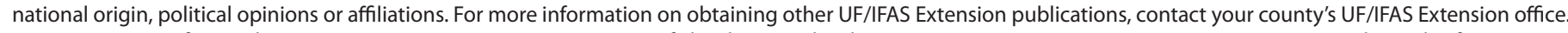
U.S. Department of Agriculture, UF/IFAS Extension Service, University of Florida, IFAS, Florida A \& M University Cooperative Extension Program, and Boards of County Commissioners Cooperating. Nick T. Place, dean for UF/IFAS Extension. 
Ephraim Goeze since their walking movement was similar to that of a bear. Despite being described as a bear, they are more closely related to arthropods. There are five segments in a tardigrade's body and they have four pairs of jointless legs with sucking disk claws on the end of each leg (Romano III 2003). The head of the tardigrade is composed of a hardened stylet, a probe-like mouthpart, and a muscular pharynx used for feeding.

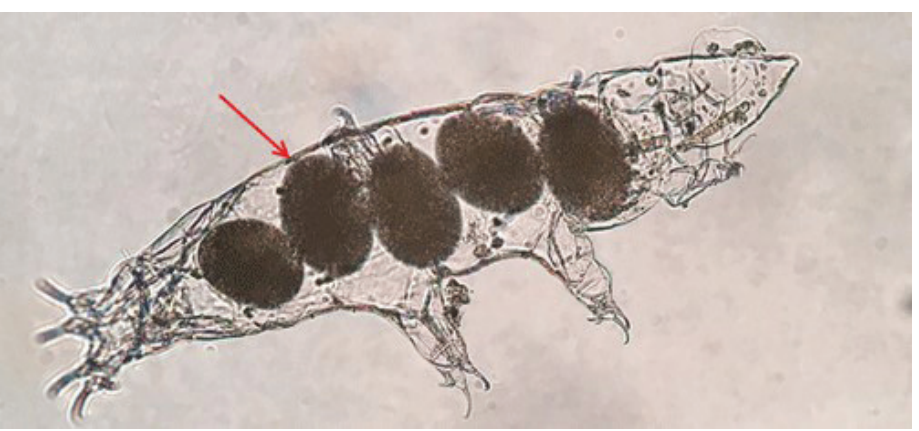

Figure 3. Image of eggs inside a tardigrade exoskeleton.

Credits: J. Parr McQueen, University of Florida

\section{Classification}

There are over 1,300 described tardigrade species which compose the three main classes: Eutardigrada, Mesotardigrada, and Heterotardigrada. These classes of tardigrades are distinguished by their physiological features and the habitats where they reside. Tardigrades of different classes differ in head size, segmentation shape and number, and the number of claws on each toe. Mesotardigrada is composed of one species, Thermozodium esakii, which was found in a hot spring in Japan; however, this species can no longer be found after its habitat was destroyed by an earthquake (Schill 2018). Mesotardigrada is not considered to be an official class by some taxonomists.

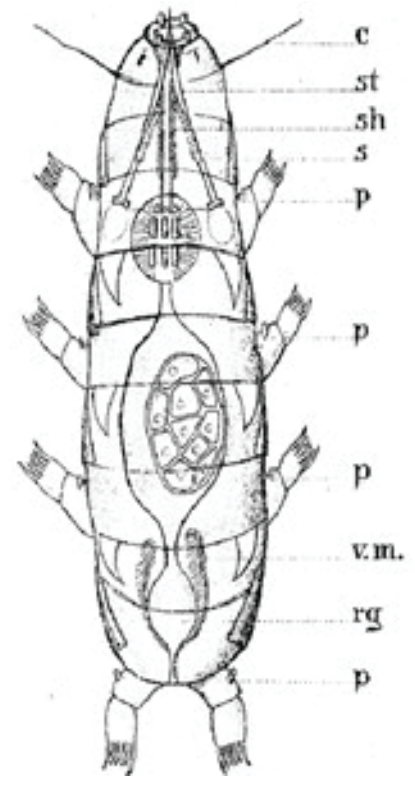

Figure 4. Illustration of Thermozodium esakii.

Credits: Gilbert Rahm (1937)
Eutardigrades are characterized by having a cloaca (reproductive and excretory vent) with a straight midgut, a Malpighian tubule system (a type of digestive system), and two double claws on each leg (Schill 2018). Recently, scientists have begun to use molecular genetics to better distinguish between different species of tardigrades and to build a more accurate phylogenetic tree.

Heterotardigrades consist of marine, freshwater, and semiterrestrial species. Tardigrades in this family also tend to lack cephalic sensory organs, which are a collection of cells that serve as sense receptors (Smith and Goldstein 2008).
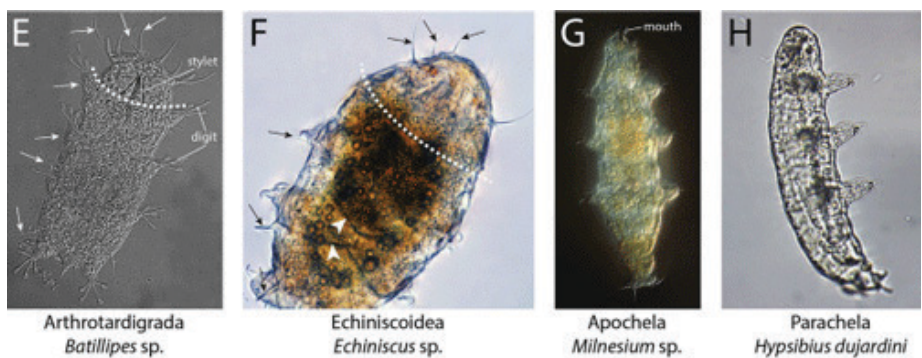

Figure 5. Different morphological features of different tardigrade species. Dashed lines indicate estimated head size.

Credits: Smith and Goldstein (2017)

\section{Selected References}

Boothby TC, Tapia H, Brozena AH, Piszkiewicz S, Smith AE, Giovannini I, Rebecchi L, Pielak GJ, Koshland D, Goldstein B. 2017. "Tardigrades use intrinsically disordered proteins to survive desiccation." Molecular Cell 65(6): 975-985.

Jönsson KI, Rabbow E, Schill RO, Harms-Ringdahl M, Rettberg P. 2008. "Tardigrades survive exposure to space in low Earth orbit.” Current Biology 18(17): 729-731.

Romano III FA. 2003. "On water bears." Florida Entomologist 86(2): 134-137.

Schill RO. 2018. Water Bears: The Biology of Tardigrades. Springer International Publishing. 418 pp.

Smith FW, Goldstein B. 2017. "Segmentation in Tardigrada and diversification of segmental patterns in Panarthropoda." Arthropod Structure \& Development 46(3): 328-340. DOI: $10.1016 /$ j.asd.2016.10.005 